\begin{tabular}{|c|c} 
JURNAL MAGISTER MANAJEMEN \\
UNIVERSITAS MATARAM \\
UNATEmber 2015
\end{tabular}

\title{
ANALISIS PENGARUH PROMOSI DAN MOTIVASI KERJA TERHADAP KEPUASAN KERJA PEJABAT STRUKTURAL ESELON III DI PEMERINTAH KABUPATEN LOMBOK BARAT
}

\author{
Muhammad Busyairi*) \\ Agusdin*) \\ Alamsyah**)
}

\begin{abstract}
This study aims to analyze: (1) the effect of promotion on job satisfaction among echelon III officials in West Lombok regency, (2) the effect of promotion on their work motivation, (3) the effect of work motivation on their satisfaction, (4) the effect of promotion on their job satisfaction through the use of work motivation. This research is categorized as a associative causal study. The technique of data collection employed literature studies and questionnaires. Population of the study covered 169 echelon III officials in West Lombok regency. The data were analyzed using Path Analysis technique. Results of the study show that: (1) promotion had a positive effect on work motivation; (2) promotion had a positive and significant effect on the work motivation (3) work motivation had a positive and significant impact on the job satisfaction (4) promotion had a positive and significant effect on the job satisfaction through the provision of motivation from the Government of West Lombok Regency. Results of the study recommend that the authorities of West Lombok regency should conduct the promotion process in a fair way by considering the educational background, competence and performance of its staff. Thus, their work motivation and job satisfaction would improve significantly.
\end{abstract}

Keywords: promotion, work motivation, and job satisfaction.

\section{Pendahuluan}

Terbentuknya 32 Dinas/Badan/Kantor dan 10 Kecamatan berdasarkan Perda Kabupaten Lombok Barat Nomor 9 Tahun 2011 tentang Organisasi Perangkat Daerah bertujuan untuk membantu pembagian tugas Bupati. Maka sudah selayaknya juga jika setiap instansi sebagai unsur Satuan Kerja Perangkat Daerah haruslah mendapatkan perhatian dari pemerintah yang merata dan adil agar dapat berdampak pada peningkatan kinerja dan pelayanan kepada masyarakat.

Berdasarkan Peraturan Pemerintah Nomor 63 tahun 2009 tentang Wewenang Pengangkatan, Pemindahan, dan Pemberhentian Pegawai Negeri Sipil disebutkan bahwa dalam pembentukan keputusan pengangkatan Pegawai Negeri Sipil akan ditentukan oleh Tim Badan Pertimbangan Jabatan dan Kepangkatan (Baperjakat) yang akan memberikan pertimbangan serta masukan kepada Bupati dalam mengambil kebijakan terkait Keputusan Bupati untuk mengisi jabatan-jabatan struktural di struktur organisasi Pemerintah Kabupaten Lombok Barat. 
Selama tahun 2013 telah dilakukan 3 kali pelantikan pejabat struktural di Lingkungan Pemerintah Kabupaten Lombok Barat, yang melibatkan eselon II, III, dan IV. Implementasi dari Peraturan Pemerintah Nomor 13 Tahun 2002 tentang Perubahan

*) Mahasiswa Magister Manajemen Pascasarjana Universitas Mataram **)Staf Pengajar Magister Manajemen Pascasarjana Universitas Mataram gangkatan Pegawai ama 12 (dua belas) tahun namun hingga saat ini masih banyak jabatan-jabatan struktural yang ada dalam Struktur Organisasi Perangkat Daerah khususnya di Kabupaten Lombok Barat diisi oleh pejabat yang tidak berkompeten di bidang tugasnya atau tidak memiliki latar belakang yang sesuai dengan pendidikannya. Menurut data yang ada di Badan Kepegawaian Daerah Kabupaten Lombok Barat dari 169 jabatan struktural eselon III sebanyak ada beberapa diisi oleh orang yang berasal dari fungsional diantaranya guru sebanyak 9 orang. Hal ini bisa menimbulkan kecemburuan dari pegawai yang berasal dari struktural disebabkan jalur karier mereka diambil oleh pegawai fungsional yang rata-rata memiliki kepangkatan lebih tinggi. Ada beberapa orang juga yang menempati jabatan yang jauh bertolak belakang dengan latar pendidikannya yang dapat menghambat dalam pelaksanaan jalannya pemerintahan dan pelayanan kepada masyarakat sebagai objek dari pembangunan itu sendiri.

Selama ini promosi jabatan terkesan tidak obyektif dan hanya mengakomodir kepentingan orang-orang yang memiliki kedekatan dengan lingkar kekuasaan, sehingga siapapun dengan kedekatannya dapat menempati jabatan strategis khususnya eselon III. Kondisi ini bisa mempengaruhi motivasi dan kepuasan kerja dari pejabat struktural di Pemerintah Kabupaten Lombok Barat.

Di tahun 2014 ini Pemerintah Kabupaten Lombok Barat melakukan sebuah terobosan baru dalam hal promosi bekerjasama dengan pihak akademisi melakukan fit and proper test untuk menentukan pejabat yang akan menduduki jabatan eselon II dan eselon III (khusus untuk jabatan Camat). Kegiatan ini bertujuan untuk mengetahui kemampuan dan kompetensi dari setiap orang yang akan menduduki jabatan Kepala Satuan Kerja Perangkat Daerah dan mendapatkan pejabat yang benar-benar berkualitas sehingga mengurangi dampak ketidak puasan dalam penempatan pejabat.

Berdasarkan uraian dan hasil penelitian diatas, maka terlihat bahwa promosi dan motivasi kerja mempengaruhi kepuasan kerja. Dengan demikian, dengan adanya promosi yang adil maka diharapkan pegawai akan termotivasi bekerja serta mempunyai kepuasan kerja yang optimal pula sehingga hubungan timbal balik antara organisasi dan karyawan menjadi balance yang tentu saja akan berpengaruh terhadap pencapaian target kerja organisasi. Sehingga peneliti tertarik untuk mengambil judul analisis pengaruh promosi dan motivasi kerja terhadap kepuasan kerja. Obyek penelitan di Pemerintah Kabupaten Lombok Barat dan subyeknya seluruh pejabat eselon III di Pemerintah Kabupaten Lombok Barat.

Berdasarkan latar belakang di atas maka dapat dirumuskan permasalahan yaitu: 1) Apakah terdapatpengaruh promosi terhadap kepuasan kerja pejabat struktural eselon III di Pemerintah Kabupaten Lombok Barat? 2) Apakah terdapat pengaruh promosi terhadap motivasi kerja pejabat struktural eselon III di Pemerintah Kabupaten Lombok Barat? 3) Apakah terdapat pengaruh motivasi kerja terhadap kepuasan kerja pejabat struktural eselon III di Pemerintah Kabupaten Lombok Barat? 


\section{TM JURNAL MAGISTER MANAJEMEN UNIVERSITAS MATARAM September 2015}

4) Apakah terdapat pengaruh promosi terhadap kepuasan kerja melalui motivasi kerja pejabat struktural eselon III di Pemerintah Kabupaten Lombok Barat?

\section{Tinjauan Teori}

Manurung (2012:147), Robbins mendefinisikan kepuasan kerja sebagai suatu sikap umum seorang individu terhadap pekerjaannya dimana dalam pekerjaan tersebut seseorang dituntut untuk berinteraksi dengan rekan sekerja dan atasan, mengikuti aturan dan kebijaksanaan organisasi, memenuhi standar produktivitas.

Menurut Umar dalam Rakhman (2013:319) dapat dijelaskan bahwa kepuasan kerja merupakan penilaian atau cerminan dari perusahaan pekerja terhadap pekerjaannya. Hal ini tampak dalam sikap positif pekerja terhadap pekerjaannya dan segala sesuatu yang dihadapi di lingkungan kerjanya. Dampak kepuasan kerja perlu dipantau dengan mengaitkan pada output yang dihasilkan.Berbagai penelitian telah dilakukan oleh para ahli dan praktisi untuk mengungkapkan kepuasan kerja (Chongho et al., 2012).

Dari definisi yang dikemukakan para ahli diatas dapat disimpulkan bahwa kepuasan kerja lebih merupakan emosi atau perasaan positif (menyenangkan) dan negatif (tidak menyenangkan) yang muncul sebagai akibat dari persepsi atau pengalaman individu tentang pekerjaan berikut aspek-aspek yang terdapat didalamnya.

Menurut Hasibuan (2005), promosi adalah perpindahan yang memperbesar authority dan responsibility karyawan ke jabatan yang lebih tinggi di dalam suatu organisasi sehingga kewajiban, hak, status dan penghasilannya semakin besar. Organisasi mengharapkan agar promosi yang diberikan mampu meningkatkan prestasi kerja yang lebih besar bagi karyawan.

Adapun menurut Sikulajuga mengungkapkan definisi dari promosi jabatan, seperti yang dikutip oleh Hasibuan (2005) yang menyatakan bahwa "Technically, a promotion is a movement within an organization from one position to another that involves either an increase in pay or an increase in status". Artinya secara teknik promosi adalah suatu perpindahan di dalam suatu organisasi dari satu posisi ke posisi lainnya yang melibatkan peningkatan upah maupun status.

Berdasarkan definisi di atas, secara ringkas dapat didefinisikan promosi adalah proses perpindahan dalam suatu organisasi dari suatu jabatan ke jabatan lainnya yang lebih tinggi diikuti oleh tanggung jawab dan penghasilan yang lebih tinggi pula.

Menurut Winardi (2007:1), motivasi berasal dari kata motivation yang berarti menggerakkan. Motivasi merupakan hasil sejumlah proses yang bersifat internal atau eksternal bagi seorang individu, yang menyebabkan timbulnya sikap antusias dalam 
hal melaksanakan kegiatan- kegiatan tertentu. Salah satu teori motivasi yang di kemukakan dan dibahas adalah Herzberg's two factor theory yang diusulkan oleh Frederick Herzberg dalam Hasibuan (1996:108) menyatakan ada 2 (dua) jenis faktor yang mendorong seseorang untuk berusaha mencapai kepuasan dan menjauhkan diri dari ketidakpuasan. Dua faktor itu disebutnya faktor hygiene (faktor ekstrinsik) dan faktor motivator (faktor intrinsik). Faktorhygiene memotivasi seseorang untuk keluar dari ketidakpuasan, termasuk di dalamnya adalah hubungan antar manusia, imbalan, kondisi lingkungan dan sebagainya. Sedangkan faktor motivator memotivasi seseorang untuk berusaha mencapai kepuasan, yang termasuk di dalamnya adalah tanggungjawab, pengakuan, kemajuan tingkat kehidupan dan sebagainya.

Berdasarkan definisi di atas, secara ringkas dapat didefinisikan motivasi kerja sebagai suatu dorongan yang muncul dari dalam diri seseorang untuk melakukan suatu pekerjaan guna mencapai tujuan pribadi dan organisasi dalam rangka memenuhi keinginan atau kebutuhannya.

Penelitian yang dilakukan oleh Usop, A.M. (2013:245-252) tentang hubungan prestasi kerja dan kepuasan kerja antara guru di Bagian Kota Cotabato, Philipina menunjukkan hasil bahwa ada 8 (delapan) aspek yang menentukan kepuasan kerja yaitu kebijakan sekolah, supervisi, gaji, hubungan inter-personal, kesempatan promosi/pertumbuhan profesional, kondisi kerja, pekerjaan itu sendiri, pencapaian, dan tanggung jawab.

\section{Kerangka Konseptual dan Hipotesis}

Adapun untuk menjawab permasalahan dan guna mencapai tujuan penelitian serta mempermudah memahami pemahaman teori yang ada maka dibuatlah kerangka berpikir sebagai berikut:

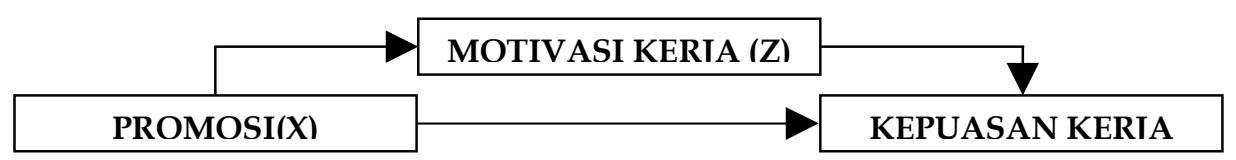

\section{Gambar 1. Kerangka Konseptual Penelitian}

Hipotesis merupakan jawaban yang sifatnya sementara terhadap permasalahan yang diajukan.Hipotesis dalam penelitian ini adalah:

$\mathrm{H}_{1}$ : Terdapat pengaruh yang signifikan promosi terhadap kepuasan kerja pejabat struktural eselon III di Pemerintah Kabupaten Lombok Barat.

$\mathrm{H}_{2}$ : Terdapat pengaruh yang signifikan promosi terhadap motivasi kerja pejabat struktural eselon III di Pemerintah Kabupaten Lombok Barat.

$\mathrm{H}_{3}$ : Terdapat pengaruh yang signifikan motivasi kerja terhadap kepuasan kerja pejabat struktural eselon III di Pemerintah Kabupaten Lombok Barat.

$\mathrm{H}_{4}$ : Terdapat pengaruh yang signifikan promosi terhadap kepuasan kerja melalui motivasi kerja pada pejabat struktural eselon III di Pemerintah Kabupaten Lombok Barat.

\section{Metode Penelitian}




\section{$J M M$ UNRAM

Jenis penelitian yang digunakan adalah penelitian asosiatif kausal. Umar (2008) mendefinisikan penelitian asosiatif kausal sebagai penelitian yang melakukan analisis pengaruh dari satu atau lebih variabel terhadap variabel lainnya. Metode penelitian ini akan digunakan untuk mengetahui pengaruh variabel independen terhadap variabel dependen dan intervening.

Penelitian ini dimaksudkan untuk memberikan gambaran tentang adanya pengaruh promosi dan motivasi kerja terhadap kepuasan kerja Pejabat Struktural Eselon III di Pemerintah Kabupaten Lombok Barat secara simultan dan parsial, maka jenis penelitian yang sesuai adalah menggunakan pendekatan kuantitatif.

Populasi adalah kumpulan dari seluruh elemen atau individu- individu yang merupakan sumber informasi dalam suatu riset (Sumarsono, 2004).Apabila seseorang ingin meneliti semua elemen yang ada dalam wilayah penelitian, maka penelitiannya merupakan penelitian populasi, studi atau penelitiannya juga disebut studi polulasi atau studi sensus (Arikunto, 2006:130).Populasi dalam penelitian ini adalah seluruh pejabat struktural eselon III di Pemerintah Kabupaten Lombok Barat sebanyak 169 (seratus enam puluh sembilan) orang.

Keseluruhan populasi dijadikan responden dalam penelitian ini yaitu seluruh pejabat eselon III di Pemerintah Kabupaten Lombok Barat sebanyak 169 (seratus enam puluh sembilan) orang. Dengan demikian penelitian ini adalah penelitian populasi atau sensus.

\section{Analisis Data dan Pembahasan}

\subsection{Analisis Data}

Penyajian data mengenai identitas responden untuk memberikan gambaran tentang keadaan responden baik dilihat dari jenis kelamin, umur dan pendidikan terakhir, masa kerja, golongan.

\section{Tabel 1.}

Distribusi Responden Berdasarkan Jenis Kelamin, Umur, dan Tingkat Pendidikan

\begin{tabular}{clcc}
\hline No $\quad$ Karakteristik & $\begin{array}{c}\text { Jumlah } \\
\text { (Orang) }\end{array}$ & $\begin{array}{c}\text { Persentase } \\
(\%)\end{array}$ \\
\hline Jenis Kelamin & & \\
$1 \quad$ Laki-laki & 104 & 82 \\
$2 \quad$ Perempuan & 23 & 18 \\
Umur & & \\
$1 \quad \leq 40$ tahun & 8 & 7 \\
$2 \quad 41-50$ tahun & 55 & 43 \\
$3 \quad \geq 51$ & 64 & 50 \\
Tingkat Pendidikan & & 1 \\
$1 \quad$ SMA & 1 & 2 \\
$2 \quad$ Diploma & 2 & 82 \\
$3 \quad$ S1 & 104 & 15 \\
$4 \quad$ S2 & 20 & \\
Masa Kerja & & \\
\hline
\end{tabular}




\section{JMM JURNaL Masistrer MAMASEEEN UNIVERSITAS MATARAM September 2015}

\begin{tabular}{clcc}
\hline 1 & $\leq 10$ tahun & 2 & 2 \\
2 & $11-20$ tahun & 30 & 23 \\
3 & $21-30$ tahun & 75 & 59 \\
4 & $\geq 31$ & 20 & 16 \\
Golongan & & \\
1 & III/c & 2 & 2 \\
2 & III/d & 23 & 18 \\
3 & IV/a & 67 & 52 \\
4 & IV/b & 35 & 28 \\
\hline
\end{tabular}

Sumber: Data Primer, diolah.

Responden berjenis kelamin laki-laki, yaitu sebanyak104 orang atau 82 persen dan sisanya adalah responden yang berjenis kelamin perempuan, yaitu sebanyak 23 orang atau 18 persen. Jadi pada penelitian ini lebih dominan responden laki-laki daripada perempuan yang memberikan tanggapan pengaruh promosi dan motivasi kerja terhadap kepuasan kerja pejabat struktural eselon III di Pemerintah Kabupaten Lombok Barat. Untuk umur responden dalam penelitian ini didominasi oleh umur $\geq$ 51 tahun yaitu sebanyak 64 orang atau 50 persen, umur 41-50 tahun sebanyak 55 orang atau 43 persen, umur $\leq 40$ sebanyak 8 orang atau 7 persen. Untuk tingkat pendidikan Pejabat Struktural Eselon III di Pemerintah Kabupaten Lombok Barat didominasi oleh tingkat pendidikan jenjang S1 sebanyak 104 orang atau 82 persen, S2 sebanyak 20 orang atau 15 persen, Diploma sebanyak 2 orang atau 2 persen, dan SMA sebanyak 1 orang atau 1 persen. Untuk masa kerja responden terdiri dari 75 orang atau 59 persen dengan masa kerja 21-30 tahun, 30 orang atau 23 persen responden dengan masa kerja 11-20 tahun, 20 orang atau 16 persen responden memiliki masa kerja $\geq 31$ tahun, dan sebanyak 2 orang atau 2 persen responden memiliki masa $\leq 10$ tahun. Selanjutnya responden dengan golongan IV lebih banyak daripada yang golongan III dengan rincian sebanyak 67 orang atau 52 persen Golongan IV/a, 35 orang atau 28 persen Golongan IV/b, 23 orang atau 18 persen Golongan III/d, dan 2 orang 2 persen Golongan III/c.

Hasil penelitian ini menunjukkan bahwa secara umum promosi jabatan di Pemerintah Kabupaten Lombok Barat dinilai dilakukan dengan baik. Persepsi responden terhadap variabel promosi rata-rata sebesar 4,14.

Untuk item (1) yaitu sebanyak 92 orang dari 127 responden menyatakansetuju bahwasetiap pegawai diberikan kesempatan yang sama untuk meningkatkan karier. Hal ini juga diperkuat oleh pendapat 28 responden yang mempunyai penilaian sangat setuju dengan pernyataan tersebut. Item (2) sebanyak 41 dari 127 responden menyatakan setuju bahwa pegawai memiliki kesempatan yang sama untuk mendapatkan promosi jabatan, hal ini diperkuat oleh pendapat 41 responden lainnya yang sangat setuju dengan pernyataan tersebut. Item (3) sebanyak 73 dari 127 responden menyatakan setuju penilaian kinerja oleh atasan dapat memberikan motivasi pegawai untuk mendapatkan promosi jabatan, sementara 39 orang memberikan penilaian sangat setuju. Item (4) sebanyak 93 dari 127 responden menyatakan setuju dengan pernyataan dalam penentuan promosi jabatan didasarkan atas penilaian kinerja, hal ini diperkuat oleh 23 orang lainnya yang sangat setuju dengan pernyataan tersebut. Item (5) sebanyak 78 orang dari 127 responden menyatakan setuju bahwakebijakan promosi jabatan dilakukan secara adil, ini juga 
diperkuat oleh pendapat 31 responden yang mempunyai penilaian sangat setuju dengan pernyataan tersebut. Item (6) yaitu item terakhir sebanyak 94 orang dari 127 responden menyatakan setuju bahwakebijakan promosi jabatan dilakukan atas dasar kompetensi pegawai secara adil, ini juga diperkuat oleh pendapat 26responden yang mempunyai penilaian sangat setuju dengan pernyataan tersebut.

Dari penilaian semua responden terhadap item variabel Motivasi Kerja, diperoleh rata-rata skor 4,14 artinya Motivasi KerjaPejabat Struktural Eselon III di Pemerintah Kabupaten Lombok Barat menunjukkan penilaian tinggi.

Untuk item (1) yaitu sebanyak 68 orang dari 127 responden menyatakan setuju bahwakondisi hubungan yang baik dengan rekan kerja meningkatkan motivasi kerja, hal ini juga diperkuat oleh pendapat 44 responden yang mempunyai penilaian sangat setuju dengan pernyataan tersebut. Item (2) sebanyak 73 dari 127 responden menyatakan setuju bahwa imbalan gaji dan penghasilan lainnya meningkatkan motivasi kerja, hal ini diperkuat oleh pendapat 39 responden lainnya yang sangat setuju dengan pernyataan tersebut. Item (3) sebanyak 96 dari 127 responden menyatakan setuju memiliki lingkungan kerja yang nyaman, sementara 20 orang memberikan penilaian sangat setuju. Item (4) sebanyak 76 dari 127 responden menyatakan setuju dengan pernyataan tanggung jawab yang diberikan mampu dilaksanakan dengan baik, hal ini diperkuat oleh 33 orang lainnya yang sangat setuju dengan pernyataan tersebut. Item (5) sebanyak 93 orang dari 127 responden menyatakan setuju bahwamerasa bangga memiliki keahlian, keterampilan dan kemampuan pada posisi jabatan yang sekarang, ini juga diperkuat oleh pendapat 27responden yang mempunyai penilaian sangat setuju dengan pernyataan tersebut. Item (6) sebanyak 94 orang dari 127 responden menyatakan setuju bahwajabatan yang sekarang ini menjadikan hidup lebih baik, ini juga diperkuat oleh pendapat 26 responden yang mempunyai penilaian sangat setuju dengan pernyataan tersebut.

Rata-rata skor jawaban responden menunjukan nilai sebesar 4,13. Hasil penelitian ini menunjukkan bahwa secara umum penilaian puas dari responden terhadapKepuasan Kerja Pejabat Struktural Eselon III di Pemerintah Kabupaten Lombok Barat. Berdasarkan tabel diatas, persepsi responden terhadap variabel Kepuasan Kerjauntukitem (1) kemampuan yang dimiliki, (8) melakukan sesuatu yang tidak bertentangan dengan hati nurani, (11) jaminan keamanan dalam melaksanakan pekerjaan, (13) pergaulan dengan rekan kerja, memperoleh kategori penilaian sangat puas. Sedangkan untuk item (2) pencapaian keberhasilan pekerjaan, (3) kesibukan pekerjaan, (4) kesempatan untuk maju dalam pekerjaan, (5) cara atasan menangani pegawai, (6) berkreasi dan melakukan hal yang berbeda, (7) memiliki kesempatan bekerja sendiri dalam pekerjaan, (9) tanggung jawab yang diemban, (10) pujian dan pengakuan berhasil dalam pekerjaan, (12) kebijakan organisasi, dan (14) kompetensi atasan dalam mengambil keputusan, memperoleh kategori puas.

Uji validitas dimaksud untuk menyatakan sejauh mana data yang tertampung pada suatu kuesioner akan mengukur apa yang akan diukur. Adapun teknik yang digunakan dalam menghitung validias adalah dengan menggunakan teknik korelasi product moment dengan level signifikan 5 persen pada program SPSS diperoleh hasil sebagai berikut : 


\begin{tabular}{|ccc} 
JMM & $\begin{array}{c}\text { JURNAL MAGISTER MANAJEMEN } \\
\text { UNIVERITS MATARAM } \\
\text { September 2015 }\end{array}$ \\
\hline
\end{tabular}

Tabel 2.

Hasil Uji Validitas Indikator Penelitian

\begin{tabular}{ccccc}
\hline Variabel & Item Pertanyaan & $\mathbf{r}_{\text {hitung }}$ & $\mathbf{r}_{\text {kritis }}$ & Keterangan \\
\hline & $\mathrm{X} 1.1$ & 0,710 & 0,300 & Valid \\
$\mathrm{X} 1.2$ & 0,687 & 0,300 & Valid \\
& $\mathrm{X} 1.3$ & 0,576 & 0,300 & Valid \\
& $\mathrm{X} 1.4$ & 0,604 & 0,300 & Valid \\
& $\mathrm{X} 1.5$ & 0,357 & 0,300 & Valid \\
$\mathrm{X} 1.6$ & 0,710 & 0,300 & Valid \\
\hline $\mathrm{Z} 1.1$ & 0,687 & 0,300 & Valid \\
& $\mathrm{Z} 1.2$ & 0,576 & 0,300 & Valid \\
$\mathrm{Z}$ & $\mathrm{Z} 1.3$ & 0,604 & 0,300 & Valid \\
& $\mathrm{Z} 1.4$ & 0,357 & 0,300 & Valid \\
& $\mathrm{Z} 1.5$ & 0,710 & 0,300 & Valid \\
& $\mathrm{Z} 1.6$ & 0,710 & 0,300 & Valid \\
\hline & $\mathrm{Y} 1.1$ & 0,680 & 0,300 & Valid \\
& $\mathrm{Y} 1.2$ & 0,759 & 0,300 & Valid \\
& $\mathrm{Y} 1.3$ & 0,767 & 0,300 & Valid \\
& $\mathrm{Y} 1.4$ & 0,354 & 0,300 & Valid \\
& $\mathrm{Y} 1.5$ & 0,354 & 0,300 & Valid \\
& $\mathrm{Y} 1.6$ & 0,759 & 0,300 & Valid \\
$\mathrm{Y}$ & $\mathrm{Y} 1.7$ & 0,588 & 0,300 & Valid \\
& $\mathrm{Y} 1.8$ & 0,761 & 0,300 & Valid \\
& $\mathrm{Y} 1.9$ & 0,678 & 0,300 & Valid \\
& $\mathrm{Y} 1.10$ & 0,670 & 0,300 & Valid \\
& $\mathrm{Y} 1.11$ & 0,668 & 0,300 & Valid \\
& $\mathrm{Y} 1.12$ & 0,588 & 0,300 & Valid \\
& $\mathrm{Y} 1.13$ & 0,761 & 0,300 & Valid \\
& $\mathrm{Y} 1.14$ & 0,608 & 0,300 & Valid \\
\hline
\end{tabular}

Sumber: Data Primer, diolah.

Berdasarkan Tabel 2 diatas, dapat dilihat hasil dari pengujian validitas untuk kuesioner penelitian secara keseluruhan adalah valid. Hal ini diketahui dengan melihat perbandingan antara nilai r-hitung dengan nilai r-kritis. Jika r-hitung lebih besar dari r-kritis, maka kuesioner dapat dikatakan valid begitu juga sebaliknya jika r-hitung lebih kecil dari r-kritis maka kuesioner tersebut dinyatakan tidak valid.

Reliabilitas adalah tingkat kemampuan instrumen penelitian untuk mengumpulkan data secara tetap dari sekelompok individu (Nawawi, 1995). Reliabilitas menunjukkan pada konsisiten dan stabilitas hasil skala pengukuran tertentu. Pengujian reliabilitas ini dilakukan dengan menggunakan formula alpha pada program SPSS diperoleh hasil sebagai berikut :

Tabel 3.

Hasil Uji Reliabilitas Variabel Penelitian

\begin{tabular}{ccc}
\hline Variabel & Cronbach's Alpha & Keterangan \\
\hline $\mathrm{X}$ & 0,813 & Reliabel \\
$\mathrm{Z}$ & 0,813 & Reliabel \\
$\mathrm{Y}$ & 0,917 & Reliabel \\
\hline
\end{tabular}


Sumber: Data Primer, diolah.

Berdasarkan pada Tabel 3 diatas, dapat diketahui bahwa nilai Cronbach's Alpha pada masing-masing variabel menunjukkan nilai yang disyaratkan sebesar 0,600 dengan demikian keseluruhan pernyataan didalam kuisioner adalah reliabel, karena telah memenuhi syarat minimal sehingga seluruh data yang didapatkan selama proses penelitian dapat dianalisis lebih lanjut.

Sebelum melakukan uji hipotesis, data perlu diuji agar memenuhi kriteria Best Linear Unbiased Estimator (BLUE) sehingga dapat menghasilkan parameter penduga yang sahih (Supramono \& Haryanto, 2005) yaitu dengan menguji Normalitas, Autokorelasi, Multikolinieritas, Heteroskedastisitas dan Linearitas.

Uji normalitas bertujuan untuk mengetahui apakah data masing-masing varians diambil dari populasi yang berdistribusi normal. Cara menentukan data berdistribusi normal atau tidak dalam penelitian ini menggunakan rasio skewness dan rasio kurtosis.

Rasio skewness dan rasio kurtosis dapat dijadikan petunjuk apakah suatu data berdistribusi normal atau tidak. Rasio skewness adalah nilai skewnes dibagi dengan standard error skewness; sedang rasio kurtosis adalah nilai kurtosis dibagi dengan standard error kurtosis. Sebagai pedoman, bila rasio kurtosis dan skewness berada di antara -2 hingga +2, maka distribusi data adalah normal (Santoso, 2000:53 dalam Setyadharma, 2010). Untuk uji normalitas dilakukan dengan menggunakan program aplikasi SPSS Statistics 17.0. dengan hasil sebagai berikut :

Tabel 4.

Hasil Uji Normalitas Data

\begin{tabular}{lccccc}
\hline & \multicolumn{2}{c}{ Skewness } & \multicolumn{2}{c}{ Kurtosis } \\
\cline { 3 - 5 } & & Statistic & Std. Error & Statistic & Std. Error \\
\hline Unstandardized & Residual & -.384 & .215 & -.288 & .427 \\
Valid N (listwise) & & & & & \\
\hline
\end{tabular}

Sumber: Data Primer, diolah.

Berdasarkan Tabel 4 diatas terlihat bahwa rasio skewness $=-0,384 / 0,215=-1,786$; sedangkan rasio kurtosis $=-0,288 / 0,427=-0,675$. Karena rasio skewness dan rasio kurtosis berada diantara -2 hingga +2 , maka dapat disimpulkan bahwa dalam pengujian ini memiliki penyebaran data residual berdistribusi normal.

Uji Autokorelasi dilakukan untuk menjamin fungsi terhindar dari terjadinya hubungan antara variabel random dari responden yang berdekatan. Pengujian dilakukan dengan uji Durbin Watson (DW) test. Uji ini hanya digunakan untuk autokorelasi tingkat satu (first order autocorrelation) dan menyaratkan adanya intercept dalam model regresi dan tidak ada variabel lagi diantara variabel penjelas. Hasilnya sebagai berikut : 


\section{JMM JUNRa Macistrer ManNaEkEN \\ UNRAM \\ UNIVERSITAS MATARAM \\ September 2015}

Tabel 5.

Hasil Uji Autokorelasi Data

\begin{tabular}{cccccc}
\hline Model & R & R Square & $\begin{array}{l}\text { Adjusted } \\
\text { R Square }\end{array}$ & $\begin{array}{c}\text { Std. Error of the } \\
\text { Estimate }\end{array}$ & Durbin-Watson \\
\hline 1 & $.839 \mathrm{a}$ & .704 & .699 & .21140 & 1.803 \\
\hline
\end{tabular}

Sumber: Data Primer, diolah.

Berdasarkan Tabel 5 diatas terlihat nilai Durbin-Watson sebesar 1,803 akan dibandingkan dengan menggunakan derajat kepercayaan 5 persen. Jumlah sampel 127 dan jumlah variabel bebas 2, maka di Tabel Durbin-Watson akan didapat nilai $\mathrm{d}_{\mathrm{L}}$ dan $\mathrm{d}_{\mathrm{U}}$ sebesar 1,613 dan 1,736. Nilai Durbin-Watson terletak diantara $\mathrm{d}_{\mathrm{U}}$ dan $4-\mathrm{d}_{\mathrm{U}}($ $d_{U}<d^{*}<\left(4-d_{U}\right)$ atau 1,736 $<1,803<2,264$ maka $\mathrm{H}_{0}$ diterima. Hal ini dapat disimpulkan bahwa tidak terdapat autokorelasi pada model regresi yang akan dilakukan dalam penelitian ini.

Hasil uji multikolinieritas diketahui bahwa nilai Variance Inflation Factor (VIF) masing-masing variabel lebih kecil (tidak melebihi) dari angka 10, demikian juga nilai Tolerance lebih besar dari pada 0,01, sehingga dapat disimpulkan bahwa model tersebut tidak terjadi adanya multikolinieritas. Berikut ini akan ditampilkan hasil uji multikolinieritas pada Tabel 6 :

Tabel 6.

Hasil Uji Multikolinieritas Data

\begin{tabular}{|c|c|c|c|c|c|c|c|c|}
\hline \multirow{2}{*}{\multicolumn{2}{|c|}{ Model }} & \multicolumn{2}{|c|}{$\begin{array}{l}\text { Unstandardized } \\
\text { Coefficients }\end{array}$} & \multirow{2}{*}{$\begin{array}{c}\begin{array}{c}\text { Standardized } \\
\text { Coefficients }\end{array} \\
\text { Beta }\end{array}$} & & \multirow[t]{2}{*}{ Sig. } & \multicolumn{2}{|c|}{$\begin{array}{l}\text { Collinearity } \\
\text { Statistics }\end{array}$} \\
\hline & & B & Std. Error & & & & Tolerance & VIF \\
\hline \multirow[t]{3}{*}{1} & (Constant) & 0,571 & .208 & & 2.745 & .007 & & \\
\hline & Promosi & 0.529 & .158 & .517 & 3.348 & .005 & .208 & 4.535 \\
\hline & Motivasi Kerja & 0.330 & 157 & .323 & -2.102 & .014 & .208 & 4.535 \\
\hline
\end{tabular}

Sumber: Data Primer, diolah.

Uji heteroskedastisitas dilakukan untuk mengetahui ada tidaknya perbedaan varian. Pada penelitian ini menggunakan uji heteroskedastisitas yang mudah yang dapat diaplikasikan di SPSS, yaitu Uji Glejser dengan hasil sebagai berikut :

Tabel 7.

Hasil Uji Heteroskedastisitas Data

\begin{tabular}{|c|c|c|c|c|c|c|c|}
\hline \multirow{2}{*}{\multicolumn{2}{|c|}{ Model }} & \multicolumn{2}{|c|}{$\begin{array}{c}\text { Unstandardized } \\
\text { Coefficients }\end{array}$} & \multirow{2}{*}{$\begin{array}{c}\begin{array}{c}\text { Standardized } \\
\text { Coefficients }\end{array} \\
\text { Beta } \\
\end{array}$} & \multirow[t]{2}{*}{$\mathrm{t}$} & \multirow[t]{2}{*}{ Sig. } & \multirow[t]{2}{*}{ Keputusan } \\
\hline & & B & Std. Error & & & & \\
\hline \multirow[t]{3}{*}{1} & (Constant) & -.074 & .132 & & -.562 & .575 & \\
\hline & Promosi & .235 & .354 & .657 & .664 & .508 & $\begin{array}{c}\text { Tidak Ada } \\
\text { Heteroskedastisitas }\end{array}$ \\
\hline & Motivasi Kerja & -.178 & .353 & -.500 & -.506 & .614 & $\begin{array}{c}\text { Tidak Ada } \\
\text { Heteroskedastisitas }\end{array}$ \\
\hline
\end{tabular}




\section{$J M M$ UNRAM

Sumber: Data Primer, diolah.

Berdasarkan Tabel 7 diatas nilai t-statistik dari seluruh variabel penjelas tidak ada yang signifikan secara statistik, sehingga dapat disimpulkan bahwa model ini tidak mengalami masalah heteroskedastisitas.

Uji linieritas digunakan untuk melihat ada tidaknya autokorelasi dalam suatu model regresi. Cara menentukan data linieritas atau tidak dalam penelitian ini dengan melihat dari nilai signifikansi pada nilai Linearity. Apabila nilaisignifikansi lebih kecil dari 0,05 maka variabel tersebut bersifat linier dengan variabel lain (Widharto, 2010 dalam Siswanto 2012).Untuk uji Linearitas dilakukan dengan menggunakan SPSS dengan hasil sebagai berikut :

Tabel 8.

Hasil Uji Linieritas Data

\begin{tabular}{lrrrrrrr}
\hline Equation & \multicolumn{4}{c}{ Model Summary } & \multicolumn{3}{c}{ Parameter Estimates } \\
\cline { 2 - 8 } & R Square & \multicolumn{1}{c}{ F } & df1 & df2 & Sig. & Constant & b1 \\
\hline Promosi & .992 & 15441.856 & 1 & 125 & .000 & .007 & .999 \\
Motivasi & .703 & 296.369 & 1 & 125 & .000 & .574 & .859 \\
Kepuasan Kerja & .702 & 294.527 & 1 & 125 & .000 & .585 & .856 \\
\hline
\end{tabular}

Sumber: Data Primer, diolah.

Berdasarkan Tabel 8 diatas uji linieritas didapatkan hasil bahwa variabel independen (promosi dan motivasi kerja) setelah diregresi, memiliki nilai signifikansi yang lebih kecil dari 0,05 maka variabel tersebut bersifat linier dengan variabel lain.

Hasil uji hipotesis Untuk mengetahui pengaruh variabel Promosi $(X)$ terhadap Motivasi Kerja (Z) dapat dilihat pada output SPSS sebagai berikut:

Tabel 9.

Pengaruh Langsung Promosi $(X)$ terhadap Motivasi Kerja $(\mathrm{Z})$

\begin{tabular}{ccccccc}
\hline $\begin{array}{c}\text { Pengaruh antar } \\
\text { Variabel }\end{array}$ & R Square & Beta & $\begin{array}{c}\text { F } \\
\text { hitung }\end{array}$ & t hitung & Sig. & Keterangan \\
\hline$(X)$ & 0,992 & 0,996 & 15.441 & 124,265 & 0,000 & $\begin{array}{c}\text { Ada } \\
\text { pengaruh }\end{array}$ \\
\hline
\end{tabular}

Sumber: Data Primer, diolah.

Besarnya angka $\mathrm{R}$ Square $\left(\mathrm{R}^{2}\right)$ adalah 0,992 dimana angka tersebut menunjukkan besarnya variasi atau perubahan variabel Promosi terhadap variabel Motivasi Kerja Pejabat Struktural Eselon III di Pemerintah Kabupaten Lombok Barat dengan cara menghitung koefisien determinasi (KD) dengan menggunakan rumus $\mathrm{KD}=\mathrm{r}^{2} \mathrm{X} 100 \%=0,992 \times 100 \%=99,20$ persen. Angka tersebut mempunyai maksud bahwa kontribusi Promosi terhadap Motivasi Kerja adalah sebesar 99,20 persen. Adapun sisanya sebesar 0,80 persen $(100 \%$ - 99,20\%) merupakan kontribusi faktor lain yang tidak termasuk dalam penelitian ini. Dengan kata lain, variabel Motivasi Kerja yang dapat diterangkan dengan menggunakan variabel Promosi adalah sebesar 99,20 persen, sedangkan pengaruh sebesar 0,80 persen disebabkan oleh variabelvariabel lain di luar model penelitian ini. 
Analisis jalur pada penelitian ini dapat pula disajikan dalam bentuk persamaan sebagai berikut:

$$
Z=0,996 X+0,089 \varepsilon 1
$$

Hasil perhitungan regresi pada Tabel 9 dapat dijelaskan bahwa nilai koefisien regresi variabel Promosi (X), adalah sebesar 0,996. Artinya jika Promosi berubah satu satuan, maka Motivasi Kerja (Z) akan berubah sebesar 0,996 dengan asumsi variabel lainnya tetap. Koefisien regresi yang bertanda positif menunjukkan pengaruh yang searah antara Promosi dengan Motivasi Kerja. Artinya apabila Promosi meningkat maka Motivasi Kerja Pejabat Struktural Eselon III di Pemerintah Kabupaten Lombok Barat akan meningkat, begitu juga sebaliknya.

Nilai signifikansi untuk variabel Promosi adalah sebesar 0,000. Nilai probabilitas signifikansi tersebut lebih kecil dari probabilitas 0,05 atau 0,000 < 0,05, artinya bahwa koefisien jalur tersebut terbukti signifikan. Jadi ada pengaruh yang signifikan antara Promosi terhadap Motivasi Kerja Pejabat Struktural Eselon III di Pemerintah Kabupaten Lombok Barat.

Untuk melihat bagaimana pengaruh secara parsial antara Promosi terhadap Motivasi Kerja Pejabat Struktural Eselon III di Pemerintah Kabupaten Lombok Barat digunakan uji t. Dari informasi Tabel 9, maka dapat dilihat bahwa nilai t hitung positif untuk variabel Promosi sebesar 124,265. Untuk menemukan jawaban atas hipotesis yang ada maka perlu dibandingkan antara $t$ hitung dengan $t$ tabel.

Dengan menggunakan tingkat keyakinan 95 persen dimana alfa 5 persen, $\mathrm{df}$ (degree of freedom) $\mathrm{n}-1=127-1=126$, sehingga diperoleh hasil untuk $\mathrm{t}$ tabel sebesar 1,991 . Karena $t$ hitung dari variabel bebas lebih besar dari $t$ tabel $(>1,991)$, maka dapat disimpulkan bahwa terdapat pengaruh yang signifikan dari Promosi terhadap Motivasi Kerja Pejabat Struktural Eselon III di Pemerintah Kabupaten Lombok Barat.

Untuk mengetahui pengaruh variabel Promosi (X) dan Motivasi Kerja (Z) terhadap Kepuasan Kerja (Y) dapat dilihat pada output SPSS (Lampiran 6) yang dirangkum pada Tabel 4.17. sebagai berikut:

Tabel 10.

Pengaruh Langsung Promosi (X) dan Motivasi Kerja (Z) terhadap Kepuasan Kerja (Y)

\begin{tabular}{ccccccc}
\hline $\begin{array}{c}\text { Pengaruh antar } \\
\text { Variabel }\end{array}$ & $\begin{array}{c}\text { R } \\
\text { Square }\end{array}$ & Beta & F hitung & t hitung & Sig. & Keterangan \\
\hline$(\mathrm{X} \longrightarrow \longrightarrow$ ( $\longrightarrow$ ) & & 0,517 & & 3,348 & 0,005 & $\begin{array}{c}\text { Ada } \\
\text { pengaruh } \\
\text { Ada } \\
\text { pengaruh }\end{array}$ \\
\hline
\end{tabular}

Sumber: Data Primer, diolah.

Besarnya angka $\mathrm{R}$ Square $\left(\mathrm{R}^{2}\right)$ adalah 0,699 , angka tersebut dapat digunakan untuk melihat besarnya variasi atau perubahan variabel Promosi $(X)$ dan Motivasi Kerja (Z) terhadap Kepuasan Kerja (Y) dengan cara menghitung koefisien determinasi (KD) dengan menggunakan rumus $\mathrm{KD}=\mathrm{r}^{2} \times 100 \%=0,699 \times 100 \%=$ 69,90 persen. Angka tersebut mempunyai maksud bahwa kontribusi Promosi dan Motivasi Kerja terhadap Kepuasan Kerja adalah sebesar 69,90 persen. Adapun sisanya sebesar 30,10 persen $(100 \%$ - 69,90\%) merupakan kontribusi faktor lain. Dengan kata lain, variabel Kepuasan Kerja Pejabat Struktural Eselon III di 


\section{$J M M$ UNRAM

Pemerintah Kabupaten Lombok Barat yang dapat diterangkan dengan menggunakan variabel Promosi dan Motivasi Kerja sebesar 69,90 persen, sedangkan kontribusi sebesar 30,10 persen disebabkan oleh variabel-variabel lain diluar model ini. berikut:

Analisis jalurnya dapat pula disajikan dalam bentuk persamaan sebagai

$$
Y=0,517 X+0,323 Z+0,549 \varepsilon 2
$$

Hasil perhitungan regresi pada Tabel 10 dapat dijelaskan sebagai berikut: (a) Nilai koefisien regresi variabel Promosi $(X)$, adalah sebesar 0,517. Artinya jika Promosi berubah satu satuan, maka Kepuasan Kerja (Y) akan berubah sebesar 0,517 dengan asumsi variabel lainnya tetap. Koefisien regresi yang bertanda positif menunjukkan pengaruh yang searah antara Promosi dengan Kepuasan Kerja Pejabat Struktural Eselon III di Pemerintah Kabupaten Lombok Barat. Artinya apabila Promosi meningkat maka Kepuasan Kerja Pejabat Struktural Eselon III di Pemerintah Kabupaten Lombok Barat akan meningkat, begitu juga sebaliknya. (b) Nilai koefisien regresi variabel Motivasi Kerja (Z), adalah sebesar 0,323. Artinya jika Motivasi Kerja berubah satu satuan, maka Kepuasan Kerja (Y) akan berubah sebesar 0,323 dengan asumsi variabel lainnya tetap. Koefisien regresi yang bertanda positif menunjukkan pengaruh yang searah antara Motivasi Kerja dengan Kepuasan Kerja Pejabat Struktural Eselon III di Pemerintah Kabupaten Lombok Barat. Artinya apabila Motivasi Kerja meningkat maka Kepuasan Kerja Pejabat Struktural Eselon III di Pemerintah Kabupaten Lombok Barat akan meningkat, begitu juga sebaliknya. (c) Nilai koefisien determinasi berganda $\left(\mathrm{r}^{2}\right)$ dari persamaan regresi linier berganda di atas adalah sebesar 0,699 atau 69,90 persen, artinya variabel Promosi mempengaruhi Kepuasan Kerja melalui Motivasi Kerja Pejabat Struktural Eselon III di Pemerintah Kabupaten Lombok Barat sebesar 0,699 atau 69,90 persen. Sedangkan sisanya sebesar 0,301 atau 30,10 persen Kepuasan Kerja dipengaruhi oleh variabel lain di luar model penelitian ini.

Berdasarkan Tabel 10, diperoleh nilai F hitung sebesar 147,593. Kemudian, dengan menggunakan tingkat keyakinan 95 persen, alfa 5 persen, df1(jumlahvariabel $-1)=2$, dan df $2(n-k)=127-3=124$, sehingga diperoleh hasil untuk $F$ tabel sebesar 2,680 (pada Lampiran 8). Dengan demikian F hitung lebih besar daripada F tabel $(147.593>2,680)$ maka dapat disimpulkan bahwa terdapat pengaruh yang signifikan secara simultan atau bersama-sama antara Promosi terhadap Kepuasan Kerja melalui Motivasi Kerja Pejabat Struktural Eselon III di Pemerintah Kabupaten Lombok Barat.

Pada Tabel 10 tersebut diatas juga terlihat: (a) pengaruh promosi terhadap kepuasan kerja, nilai signifikansi untuk variabel promosi adalah 0,005. Nilai probabilitas signifikansi tersebut lebih kecil dari probabilitas $0,05(0,005<0,05)$, artinya bahwa koefisien jalur tersebut signifikan. Dengan demikian terdapat pengaruh yang signifikan antara Promosi terhadap Kepuasan Kerja Pejabat Struktural Eselon III di Pemerintah Kabupaten Lombok Barat terbukti. (b) pengaruh motivasi kerja terhadap kepuasan kerja, diketahui bahwa nilai signifikansi untuk variabel motivasi kerja adalah 0,014 . Nilai probabilitas signifikansi tersebut lebih kecil dari probabilitas $0,05(0,000<0,14)$, artinya bahwa koefisien jalur tersebut signifikan. 
Jadi ada pengaruh yang signifikan antara Motivasi Kerja terhadap Kepuasan Kerja Pejabat Struktural Eselon III di Pemerintah Kabupaten Lombok Barat terbukti.

Untuk melihat bagaimana pengaruh secara parsial antara Promosi terhadap Kepuasan Kerja melalui Motivasi Kerja Pejabat Struktural Eselon III di Pemerintah Kabupaten Lombok Barat digunakan uji t. Dari informasi pada Tabel 10, maka dapat dilihat bahwa nilai $t$ hitung positif untuk variabel Promosi sebesar 0,948, dan Motivasi Kerja sebesar 0,593. Untuk menemukan jawaban atas hipotesis yang ada maka perlu dibandingkan antara thitung dengan $\mathrm{t}$ tabel.

Dengan menggunakan tingkat keyakinan 95 persen dimana alfa 5 persen, $\mathrm{df}$ (degree of fredom) $\mathrm{n}-1=127-1=126$, sehingga diperoleh hasil untuk $\mathrm{t}$ tabel sebesar 1,991 (Lampiran 10). Karena nilai $t$ hitung variabel Promosi dan Motivasi Kerja memiliki nilai $t$ hitung yang jauh lebih besar daripada $t$ tabel $(>1,991)$, maka dapat disimpulkan bahwa terdapat pengaruh yang signifikan secara parsial atau terpisah dari Promosi terhadap Kepuasan Kerja melalui Motivasi Kerja Pejabat Struktural Eselon III di Pemerintah Kabupaten Lombok Barat.

Besarnya pengaruh tidak langsung variabel Promosi terhadap Kepuasan Kerja melalui Motivasi Kerja diperoleh melalui hasil perkalian koefisien jalur (beta) antara pengaruh langsung Promosi terhadap Motivasi Kerja dengan pengaruh langsung Motivasi Kerja terhadap Kepuasan Kerja Pejabat Struktural Eselon III di Pemerintah Kabupaten Lombok Barat. Besarnya pengaruh tidak langsung Promosi terhadap Kepuasan Kerja melalui Motivasi Kerja Pejabat Struktural Eselon III di Pemerintah Kabupaten Lombok Barat yaitu sebesar 0,322 (0,996 x 0,323).

Untuk melihat lebih jelas besarnya pengaruh tidak langsung antara variabel bebas Promosi terhadap Kepuasan Kerja melalui Motivasi Kerja Pejabat Struktural Eselon III di Pemerintah Kabupaten Lombok Barat, dapat dilihat pada Tabel 11 berikut:

\section{Tabel 11.}

Perhitungan Pengaruh Tidak Langsung Variabel Promosi terhadap Kepuasan Kerja melalui Motivasi Kerja

\begin{tabular}{lcc}
\hline \multicolumn{2}{c}{ Pengaruh Variabel } & Formula Perhitungan \\
\hline $\begin{array}{l}\text { Rangkuman Pengaruh Langsung (Direct Effect/DE) } \\
\text { X terhadap Z }\end{array}$ & 0,996 \\
$\begin{array}{l}\text { Rangkuman Pengaruh Tidak Langsung (Indirect Effect/IE) } \\
\text { X terhadap Y melalui Z } \quad \text { DEXZ x DEZY }(0,996 \times 0,323)\end{array}$ & 0,322 \\
\hline
\end{tabular}

Sumber: Data Primer, diolah.

Berdasarkan Tabel 11 dapat dilihat Promosi memberikan pengaruh tidak langsung terhadap Kepuasan Kerja Pejabat Struktural Eselon III di Pemerintah Kabupaten Lombok Barat melalui Motivasi Kerja sebesar 0,322.

Besarnya pengaruh total merupakan penjumlahan dari pengaruh langsung dan tidak langsung dari seluruh jalur setiap variabel dalam penelitian ini. Perhitungan pengaruh total akan diperlihatkan pada Tabel 12. Untuk lebih jelasnya pada tabel tersebut juga ditampilkan terlebih dahulu rangkuman perhitungan pengaruh langsung dan pengaruh tidak langsung yang telah diuraikan sebelumnya 


\section{$J M M$ UNRAM

dan selanjutnya diteruskan dengan perhitungan pengaruh total variabel-variabel dalam penelitian ini.

Tabel 12.

Perhitungan Pengaruh Total Variabel Promosi terhadap Kepuasan Kerja melalui Motivasi Kerja

\begin{tabular}{lll}
\hline \multicolumn{1}{c}{ Pengaruh Variabel } & \multicolumn{1}{c}{ Formula Perhitungan } & Hasil \\
\hline X terhadap Z & - & 0,996 \\
Pengaruh X terhadap Y & TEYX = DEXY & 0,517 \\
Pengaruh Z terhadap Y & TEYZ = DEZY & 0,323 \\
X terhadap Y melalui Z & DEXZ + DEXY $(0,996+0,517)$ & 1,513 \\
\hline
\end{tabular}

Sumber: Data Primer, diolah.

Berdasarkan hasil perhitungan Tabel 12, maka dapat dijelaskan bahwa pengaruh Promosi terhadap Kepuasan Kerja melalui Motivasi Kerja Pejabat Struktural Eselon III di Pemerintah Kabupaten Lombok Barat yaitu sebesar 1,513.

Pengujian model dalam penelitian ini menggunakan model trimming. Ridwan dan Kuncoro (2007) mengatakan bahwa model trimming adalah model yang digunakan untuk memperbaiki suatu model struktur analisis jalur dengan cara mengeluarkan dari model variabel eksogen yang koefisien jalurnya tidak signifikan. Jadi model terjadi ketika koefisien jalur diuji secara keseluruhan ternyata ada variabel yang tidak signifikan. Maka peneliti perlu memperbaiki model struktur analisis jalur yang dihipotesiskan.Hasil analisis jalur yang sudah dilakukan sebelumnya dapat digambarkan sebagimana Gambar 2 berikut:

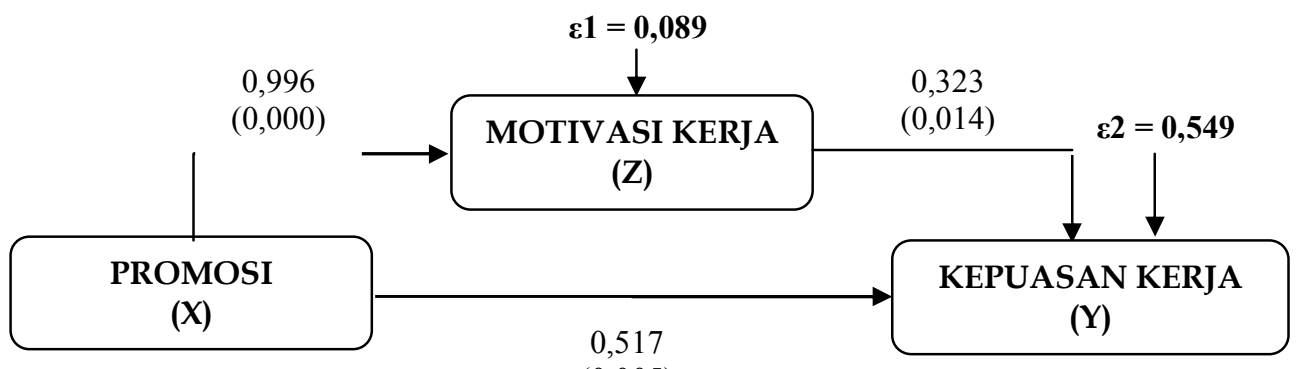

$(0,005)$

Gambar 2. Model Penelitian

Cara menggunakan model trimming adalah menghitung ulang koefisien jalur tanpa menyertakan variabel eksogen yang koefisien jalurnya tidak signifikan. Namun pada model diatas semua koefisienjalur dinyatakan signifikan sebagaimana dijelaskan pada analisis sebelumnya, sehingga tidak perlu diadakan penghitungan ulang.

\subsection{Diskusi}

Berdasarkan hasil penelitian diperoleh bahwa variabel promosi dan motivasi kerja berpengaruh terhadap Kepuasan Kerja. Hasil tersebut sesuai dengan hipotesis 


\section{JMM JURNA M MaCITTER MAMAJENEN UNIVERSITAS MATARAM September 2015}

yang diajukan serta sesuai dengan hasil penelitian-penelitian sebelumnya. Hasil penelitian ini juga sesuai dengan hasil penelitian sebelumnya.

Hipotesis pertama promosi memiliki pengaruh signifikan terhadap kepuasan kerja pejabat struktural eselon III di Pemerintah Kabupaten Lombok Barat. Hasil ini mendukung penelitian sebelumnya yang dilakukan oleh Rakhman, M. (2012: 316327) menjelaskan bahwa promosi mempunyai pengaruh yang signifikan terhadap kepuasan kerja pegawai pada Dinas Perhubungan Provinsi Kalimantan Timur. Penelitian yang dilakukan oleh Mehmood, N. (2012: 673-684) tentang faktor- faktor yang mempengaruhi kepuasan kerja pada sektor industri jasa di Pakistan menunjukkan hasil bahwa promosi jabatan mempengaruhi kepuasan kerja karyawan. Penelitian yang dilakukan oleh Usop, A.M. (2013:245-252) tentang hubungan prestasi kerja dan kepuasan kerja antara guru di Bagian Kota Cotabato, Philipina menunjukkan hasil bahwa ada 8 (delapan) aspek yang menentukan kepuasan kerja yaitu kebijakan sekolah, supervisi, gaji, hubungan inter-personal, kesempatan promosi/pertumbuhan profesional, kondisi kerja, pekerjaan itu sendiri, pencapaian, dan tanggung jawab.

Hasil analisis menunjukkan besarnya $R$ Square $\left(R^{2}\right)$ adalah 0,699, angka tersebut dapat digunakan untuk melihat besarnya variasi atau perubahan variabel Promosi terhadap variabel Motivasi Kerja Pejabat Struktural Eselon III di Pemerintah Kabupaten Lombok Barat dengan cara menghitung Koefisien Determinasinya. Angka tersebut mempunyai maksud bahwa kontribusi Promosi terhadap Motivasi Kerja Pejabat Struktural Eselon III di Pemerintah Kabupaten Lombok Barat adalah sebesar 69,90 persen. Adapun sisanya sebesar 30,10 persen dipengaruhi oleh faktor-faktor lain di luar penelitian ini.

Uji Signifikansi pengaruh Promosi terhadap Kepuasan Kerja Pejabat Struktural Eselon III di Pemerintah Kabupaten Lombok Barat dapat diketahui dengan melakukan uji hipotesis. Dengan nilai F hitung sebesar 147.593,000 dengan nilai probabilitas signifikansi sebesar 0,005. Nilai tersebut lebih kecil dari probabilitas 0,05 $(0,005<0,05)$. Hal tersebut berarti bahwa Motivasi Kerja berpengaruh signifikan terhadap Kepuasan Kerja Pejabat Struktural Eselon III di Pemerintah Kabupaten Lombok Barat.

Hipotesis kedua promosi memiliki pengaruh signifikan terhadap motivasi kerja pejabat struktural eselon III di Pemerintah Kabupaten Lombok Barat. Hasil penelitian ini juga sesuai dengan hasil penelitian sebelumnya.

Penelitian yang dilakukan oleh Hudiyah, A. (2006) menjelaskan bahwa promosi mempunyai pengaruh yang signifikan terhadap motivasi kerja karyawan pada Bank BTN Cabang Syariah. Penelitian yang dilakukan oleh Isyanto, P. (2013: 1124-1134) tentang pengaruh pengembangan karier terhadap motivasi kerja karyawan pada PT. Exvel Utama Indonesia Karawang menunjukkan bahwa faktor yang mempengaruhi motivasi kerja salah satunya adalah promosi jabatan.

Hasil analisis menunjukkan besarnya $R$ Square $\left(R^{2}\right)$ adalah 0,992, angka tersebut dapat digunakan untuk melihat besarnya variasi atau perubahan variabel Promosi terhadap Motivasi Kerja Pejabat Struktural Eselon III di Pemerintah Kabupaten Lombok Barat dengan cara menghitung Koefisien Determinasinya. Angka tersebut mempunyai maksud bahwa kontribusi Promosi terhadap Motivasi Kerja Pejabat Struktural Eselon III di Pemerintah Kabupaten Lombok Barat adalah sebesar 


\section{$J M M$ UNRAM

99,20 persen. Adapun sisanya sebesar 0,80 persen merupakan kontribusi faktor-faktor lain di luar penelitian ini.

Koefisien jalur antara variabel Promosi sebesar 0,357 secara positif terhadap Motivasi Kerja Pejabat Struktural Eselon III di Pemerintah Kabupaten Lombok Barat. Koefisien jalur ini menunjukkan pengaruh langsung dari Promosi terhadap Motivasi Kerja dalam model jalur yang telah dirumuskan. Uji signifikansi ini secara langsung dapat diketahui dengan melakukan uji hipotesis yang menunjukkan bahwa nilai probabilitas signifikansi adalah 0,001. Nilai tersebut lebih kecil dari probabilitas $0,05(0,001<0,05)$. Hal tersebut berarti bahwa Promosi menentukan tingkat Motivasi Kerja Pejabat Struktural Eselon III di Pemerintah Kabupaten Lombok Barat.

Promosi menjadi faktor penting yangmempengaruhi Motivasi Kerja. Promosi tersebut secara langsung mempengaruhi Motivasi Kerja melalui status dan tanggung jawab yang lebih tinggi dapat merangsang karyawan agar bergairah, berdisiplin tinggi, dan memperbesar produktivitas. Makadari itu, Promosi yang tepat akan menimbulkan Motivasi Kerja yang tinggi bagiPejabat Struktural Eselon III di Pemerintah Kabupaten Lombok Barat.

Hipotesis ketiga motivasi kerja memiliki pengaruh signifikan terhadap kepuasan kerja pejabat struktural eselon III di Pemerintah Kabupaten Lombok Barat. Hasil penelitian ini juga sesuai dengan hasil penelitian sebelumnya.

Penelitian yang dilakukan oleh Kurnia, A.M. (2013:1-7) untuk mengetahui pengaruh motivasi kerja terhadap kepuasan kerja dan prestasi kerja karyawan PT. Askes (Persero) Cabang Boyolali menunjukkan hasil motivasi kerja berpengaruh secara signifkan terhadap kepuasan kerja.Penelitian yang dilakukan oleh Dhermawan(2012) untuk mengetahui pengaruh motivasi,lingkungan kerja, kompetensi, dan kompensasi terhadap kepuasan kerja dan kinerja Pegawai di lingkungan Dinas PU Provinsi Balimenunjukkan hasil motivasi kerja berpengaruh secara signifikan terhadap kepuasan kerja.

Hasil analisis menunjukkan besarnya $R$ Square $\left(R^{2}\right)$ adalah 0,973 , angka tersebut dapat digunakan untuk melihat besarnya variasi atau perubahan variabel Motivasi Kerja terhadap variabel Kepuasan Kerja Pejabat Struktural Eselon III di Pemerintah Kabupaten Lombok Barat dengan cara menghitung Koefisien Determinasinya. Angka tersebut mempunyai maksud bahwa kontribusi Motivasi Kerja terhadap Kepuasan Kerja Pejabat Struktural Eselon III di Pemerintah Kabupaten Lombok Barat adalah sebesar 97,30 persen. Sedangkan sisanya sebesar 2,70 persen merupakan kontribusi faktor-faktor lain. Pengaruh dari variabel Motivasi Kerja terhadap Kepuasan Kerja Pejabat Struktural Eselon III di Pemerintah Kabupaten Lombok Barat adalah dapat dilihat dari Koefisien jalur.

Uji Signifikansi pengaruh Motivasi Kerja terhadap Kepuasan Kerja Pejabat Struktural Eselon III di Pemerintah Kabupaten Lombok Barat dapat diketahui dengan melakukan uji hipotesis. Dengan nilai F hitung sebesar 1.391,000 dengan nilai probabilitas signifikansi sebesar 0,005 . Nilai tersebut lebih kecil dari probabilitas 0,05 $(0,005<0,05)$. Hal tersebut berarti bahwa Motivasi Kerja berpengaruh signifikan terhadap Kepuasan Kerja Pejabat Struktural Eselon III di Pemerintah Kabupaten Lombok Barat. 
Secara teoretis, hasil penelitian sejalan dengan esensi dari teori motivasi menurut Herzberg, bahwa motivasi mendorong seseorang untuk berusaha mencapai kepuasan dan menjauhkan diri dari ketidakpuasan seperti yang telah dijelaskan sebelumnya.

Hipotesis keempat promosi memiliki pengaruh signifikan terhadap kepuasan kerja melalui motivasi kerja pejabat struktural eselon III di Pemerintah Kabupaten Lombok Barat. Hasil penelitian ini juga sesuai dengan hasil penelitian sebelumnya.

Penelitian yang dilakukan oleh Chongho, L. (2012:160-170) untuk mengetahui dimensi sosial sebagai faktor yang mempengaruhi kepuasan kerja pada perusahaan penerbangan terbesar di Korea Selatan menunjukkan hasil bahwa kepuasan kerja terdiri dari 4 (empat) faktor yaitu pekerjaan itu sendiri (motivasi, karakteristik, kewenangan, tanggung jawab), lingkungan (kondisi, pengawasan, rekan kerja), karakteristik organisasi (upah, stabilitas kerja, promosi, kebijakan organisasi), dan dimensi sosial (gengsi pekerjaan, reputasi organisasi, tanggungjawab sosial perusahaan).Menurut penelitian yang dilakukan oleh Baiq Rini Arsiyani (2012) untuk mengetahui pengaruh kompensasi terhadap kepuasan kerja melalui motivasi kerja pada Badan Keluarga Berencana dan Pemberdayaan Perempuan (BKBPP) Kabupaten Lombok Barat menunjukkan hasil bahwa motivasi kerja berpengaruh secara signifikan terhadap kepuasan kerja.Penelitian yang dilakukan oleh Khalid(2011) untuk mengetahui dampak kompensasi dan motivasi terhadapkepuasan kerja antara industri air publik dan swasta di Malaysiamenunjukkan hasil yang positif dan signifikan dari motivasi terhadap kepuasan kerja.

Hasil analisis menunjukkan besarnya $R$ Square $\left(R^{2}\right)$ adalah 3,348, angka tersebut dapat digunakan untuk melihat besarnya variasi atau perubahan variabel Promosi terhadap Kepuasan Kerja melalui Motivasi Kerja dengan cara menghitung Koefisien Determinasinya. Angka tersebut mempunyai maksud bahwa kontribusi Promosi terhadap Kepuasan Kerja melalui Motivasi Kerja Pejabat Struktural Eselon III di Pemerintah Kabupaten Lombok Barat adalah 97,30 persen. Sedangkan sisanya sebesar 2,70 persen merupakan kontribusi faktor-faktor lain.

Uji signifikansi pengaruh Promosi terhadap Kepuasan Kerja melalui Motivasi Kerja Pejabat Struktural Eselon III di Pemerintah Kabupaten Lombok Barat dapat diketahui dengan melakukan uji hipotesis. Dengan nilai t hitung sebesar 48,155 dengan nilai probabilitas signifikansi sebesar 0,000. Nilai tersebut lebih kecil dari probabilitas $0,05(0,000<0,05)$. Hal tersebut menyatakan bahwa Promosi berpengaruh signifikan terhadap Kepuasan Kerja melalui Motivasi Kerja. Uji hipotesis diatas menunjukkan bahwa hipotesis yang diajukan diterima yaitu Promosi berpengaruh positif dan signifikan terhadap Kepuasan Kerja melalui Motivasi Kerja Pejabat Struktural Eselon III di Pemerintah Kabupaten Lombok Barat.

\section{Kesimpulan dan Rekomendasi}

Berdasarkan hasil penelitian dan pembahasan yang telah dilakukan mengenai Pengaruh Promosi dan Motivasi Kerja terhadap Kepuasan Kerja Pejabat Struktural Eselon III di Pemerintah Kabupaten Lombok Barat dapat diambil beberapa kesimpulan yaitu:

a. Promosi berpengaruh positif dan signifikan terhadap Kepuasan Kerja Pejabat Struktural Eselon III di Pemerintah Kabupaten Lombok Barat. 


\section{$J M M$ UNRAM

b. Promosi berpengaruh positif dan signifikan terhadap Motivasi Kerja Pejabat Struktural Eselon III di Pemerintah Kabupaten Lombok Barat.

c. Motivasi Kerja berpengaruh positif dan signifikan terhadap Kepuasan Kerja Pejabat Struktural Eselon III di Pemerintah Kabupaten Lombok Barat.

d. Promosi berpengaruh positif dan signifikan terhadap Kepuasan Kerja melalui Motivasi Kerja Pejabat Struktural Eselon III di Pemerintah Kabupaten Lombok Barat.

Berdasarkan hasil kesimpulan diatas, selanjutnya disampaikan saran baik untuk kepentingan praktisi maupun kepentingan organisasi selanjutnya adalah sebagai berikut :

a. Untuk meningkatkan Kepuasan Kerja Pejabat Struktural Eselon III di Pemerintah Kabupaten Lombok Baratmaka promosi yang dilakukan harus memberikan kesempatan yang sama secara adil kepada semua pegawai untuk meningkatkan karier dan mendapatkan promosi dengan mempertimbangkan kinerja dan kompetensi.

b. Diharapkan penelitian ini dapat menjadi bahan masukan dan pertimbangan bagi pemegang kebijakan di Pemerintah Kabupaten Lombok Barat mampu memberikan motivasi kerja kepada Pejabat Struktural Eselon III agar tugas di bidang pemerintahan bisa berjalan dengan baik.

c. Mengacu keterbatasan dari penelitian ini maka diharapkan bagi peneliti selanjutnya agar mengembangkan penelitian ini baik dari sisi variabel, responden, metode, tempat penelitian, dan menambahkan indikator-indikator pada variabel yang digunakan serta menggunakan alat analisis yang berbeda seperti SEM (Structur Equation Model) guna mendapatkan hasil temuan penelitian yang lebih baik dan lebih akurat.

\section{Daftar Pustaka}

Arikunto, S. (2006), Prosedur Penelitian suatu Pendekatan Praktis, Jakarta : Bina Akasara.

Chongho, L., Myungsook, A., Yonghwi, N. (2012), The Social Dimension of Service Workers' Job Satisfaction : The Perspective of Flight Attendants, Journal of Service Science and Management, 5, 160-170

Hasibuan M. S. P. (2005) Manajemen Sumber Daya Manusia, Jakarta: PT. Bumi Aksara.

Kuncoro, M. (2007), Metode Kualitatitif : Teori dan Aplikasi untuk Bisnis dan Ekonomi, Unit Penerbit dan Percetakan (UPP) STIM YKPN, Yogyakarta.

Kurnia, A.M., Irum, S., Ahmed, K., dan Sultana, K. (2013), “Pengaruh Motivasi Kerja Terhadap Kepuasan Kerja dan Prestasi Kerja Karyawan (Studi pada Karyawan PT. Askes (Persero), Cabang Boyolali), Jurnal Adminstrasi Bisnis, Vol 6, No 1, 2013, 1-7.

Mehmood, N., Irum, S., Ahmed, K., dan Sultana, K., (2012), “A Study of Factors Affecting Job Satisfaction (Evidence from Pakistan), Interdiscipinary Journal Of Contemporary Research In Business, Vol 4, No 6, Oktober, 673-684.

Nawawi (1995), Manajemen Sumber Daya Manusia Untuk Bisnis yang Kompetitif, BPFE, Yogyakarta. 


\section{TMM JURNAL MAGISTER MANAJEMEN

Rakhman, M., A., Masjaya, dan Sugandi, (2013), “Faktor-Faktor yang Mempengaruhi Kepuasan Kerja Pegawai pada Dinas Perhubungan Provinsi Kalimantan Timur", eJournal Administrative Reform, Vol 1, No 1, 316-327

Robbins, S., Coulter, M. (2012), Management, Pearson Education, Inc., New Jersey.

Sumarsono, Sonny (2004),Metode Riset Sumber Daya Manusia, Yogyakarta: Graha Ilmu.

Usop, A. M., Askandar, K. Dr., Kadtong, M. L., Usop, D. A. S O. (2013), Work Performance and Job Satisfaction among Techers, International Journal of Humanities and Social Science, 3 (5), 245-252

Winardi (2007), Manajemen Perilaku Organisasi, Jakarta: Kencana Prenda Media Grup. .Peraturan Pemerintah Nomor 13 Tahun 2002 tentang Perubahan Atas Peraturan Pemerintah Nomor 100 Tahun 2000 tentang Pengangkatan PNS Dalam Jabatan Struktural

.Peraturan Pemerintah Nomor 63 Tahun 2009 tentang Wewenang Pengangkatan, Pemindahan, dan Pemberhentian Pegawai Negeri Sipil

.Peraturan Daerah Kabupaten Lombok Barat Nomor 9 Tahun 2011 tentang Organisasi Perangkat Daerah 